How to cite this article: Rodriguez-Sanchez, C., Schuitema, G., Claudy, M., \& Sancho-Esper, F. (2018). How trust and emotions influence policy acceptance: The case of the Irish water charges. British Journal of Social Psychology, 57(3), 610-629.

\title{
How trust and emotions influence policy acceptance: The case of the Irish
}

\section{water charges}

\begin{abstract}
The introduction of new policies can evoke strong emotional reactions by the public. Yet, social psychological research has paid little attention to affective determinants of individuallevel policy acceptance. Building on recent theoretical and empirical advances around emotions and decision-making, we evaluate how people's trust and integral emotions function as important antecedents of cognitive evaluations, and subsequent acceptance of policies. We test our hypotheses within a sample of Irish citizens $(n=505)$, who were subject to the introduction of water charges in 2015. In line with our hypotheses, results show that general trust in government shapes emotions regarding water charges, which in turn, directly and via expected costs and benefits, influence policy acceptance. Additionally, we find that negative emotions have a larger direct effect on policy acceptance than positive emotions. Specifically, 'anger' was the main negative emotion that influenced the acceptance of the water charge. We conclude by discussing directions for future research around emotions and policy acceptance.
\end{abstract}




\section{Background}

In democratic societies, public support is a vital pre-requisite for the introduction of new policies, and politicians may be reluctant to introduce policies that lack the backing of the public (Howes et al., 2017; Steg, Dreijerink, \& Abrahamse, 2006). Particularly when policies are aimed to safeguard the collective good like environmental or social policies, low acceptance levels can be problematic (Gärling \& Schuitema, 2007; Schuitema, Steg, \&, Rothengatter, 2010b). Yet, relatively little is understood about the social-psychological factors and mechanisms that influence individual-level acceptance and support of policies.

Policy acceptance refers to the response of a group of people to changes in the public context such as the introduction of new regulations, laws or taxes. When these regulatory changes result in price changes (e.g., government charges or taxes), policy acceptance is often defined as the tendency to evaluate this policy with some degree of favour or disfavour after its implementation (Schuitema, Steg, \& Forward, 2010a). Policy acceptance has predominantly been studied as a rational process, whereby individuals cognitively evaluate expected costs and benefits of a policy (de Borger \& Proost, 2010; Schuitema et al., 2010b). Another stream of research has conceptualised policy acceptance as a moral process, suggesting that people who have strong moral obligations to serve collective interests are more likely to support environmental or social policies (de Groot, Steg, \& Poortinga, 2013; Steg, Dreijerink, \& Abrahamse, 2005; Stern, 2000).

Far less attention has been given to the role of trust and emotions in the public acceptance of policies, although this has been acknowledged as an important research area (Perlaviciute, Steg, Hoekstra, \& Vrieling, 2017; Stoutenborough, Sturgess, \& Vedlitz, 2013). The present study aims to address this paucity by investigating the roles of emotions and trust in individual-level policy acceptance. As a case in point, we focus on the public acceptance of a water tax that was introduced in the Republic of Ireland in 2015. Before and after the 
introduction of the water tax, large-scale public protests occurred, and after 18 months the tax was suspended. In this study, we investigate how trust in the government and emotions function as important antecedents of people's cognitive evaluations and subsequent acceptance of the policy. Moreover, we examine in-depth how specific positive and negative emotions influence the acceptance of this policy. In the subsequent sections, we first provide important contextual information of the water charges in Ireland, before hypothesising how policy acceptance is influenced by trust, emotions, as well as expected costs and benefits. Finally, we discuss the theoretical and policy implications of our findings, and conclude by highlighting avenues for further research.

\section{The Irish water charges}

The implementation and subsequent abolishment of the Irish water charges in 2015 was preceded by an intense public and political debate that goes back almost 40 years. Since 1978, when the Irish water charges were abolished for the first time, water charges have been a major topic of public and political debate and still constitute a dominant theme during election campaigns (McGee, 2012ab; Ryan, 2014). The most recent debate about water charges has its origin in the financial crisis of 2008, which led to the financial bailout of the Irish government by the so-called Troika, consisting of the European Commission, the European Central Bank and the International Monetary Fund. In order to deal with the huge increase in public debt, the Irish government introduced a series of austerity measures, which included the re-introduction of household water charges and water meters.

Unlike many other austerity-measures, the re-introduction of water charges experienced particularly strong resistance from the Irish public. Many people demonstrated against the water charges, particularly in the last months before the introduction in January 2015, with some reporting figures of up to 100,000 protesters at some occasions (Holland, 2014; McGee \& McMahon, 2014; Right2Water, 2014). The reasons for the strong public objection against 
the water charges are assumed to be rooted in a wider anti-austerity sentiment, as well as a general discontent with the Irish government during this period. Indeed, many Irish expressed strong negative emotions towards the government during the protests, holding banners that referred to feelings of betrayal, frustration and to being let-down (Hearne, 2015).

Despite strong public objections, lengthy debates and great uncertainty about the actual design of the policy, water charges were effectively rolled out in 2015 . The charge varied according to the number of adults in a household (1 or $2+)$, and whether or not the occupants used wastewater services or not. The charges ranged from a maximum of $€ 260$ per year ( $2+$ adults paying for water supply and wastewater services) to a minimum of $€ 80$ per annum (1 adults paying for water supply only). The fees for households with a water meter were capped until 2019. However, public protests against the water charges did not stop, and many Irish refused to pay their water bills. In October 2015, when data for our study was collected, $39 \%$ of Irish households had not paid their water charges at least once (Irish Water, 2016). These ongoing protest and boycotts heavily influenced the elections in 2016, and soon after the formation of the new government the water charges were once again suspended. Debates about re-introduction or permanent abolishment of the water charges are currently ongoing.

This context suggests that people's distrust and (negative) feelings towards the governments had a significant influence on their evaluations of the water charges. Thus, the introduction of water charges in Ireland provides a relevant context for examining the roles of trust and emotions in the public acceptance of policies.

\section{The role of trust in policy acceptance}

Trust in public institutions is a key element that facilitates the overall working of the political process and system (Kasperson, Kasperson, Pidgeon, \& Slovic, 2003). In the context of policy acceptance, trust has been defined as people's willingness to rely on those who are 
responsible for delivering policies as a result of expecting beneficial outcomes from them (Siegrist, Cvetkovich, \& Roth, 2000). The object of trust varies in the public policy literature and while some studies investigate people's trust in government, others have focused on trust in institutions, stakeholders or individuals (Lopez-Navarro, Llorens-Monzonis, Tortosa-Edo, 2013). In the context of policy acceptance, local or central governments are generally responsible for the introduction and implementation of policies. Trust in government thus constitutes the most relevant authority in the context of this study (Harring \& Jagers, 2013). Further, it has been recognized that, depending on the context, trust has an affective and/or a cognitive dimension (Lewis \& Weigert, 1985). The affective dimension of trust refers to a set of affective beliefs about institutional behavior i.e. an institutions general trustworthiness. At a cognitive level, trust is formed on the basis of people's evaluations of an institution's competence (Metlay, 1999; Siegrist, Earle, \& Gutscher, 2003). Research shows that in the context of policy acceptance people often base decisions on affective beliefs of trustworthiness rather than on deliberate cognitive evaluations (e.g., Poortinga \& Pidgeon, 2003; 2005), particularly in situations where they lack critical information, or in situations of uncertainty (Bratspies, 2009; Earle \& Cvetkovich, 1995; Metlay, 1999; Siegrist et al., 2003).

Importantly, empirical findings suggest a direct and positive relationship between trust in government and people's support for public policies (Adaman et al., 2011; Hamma \& Jagers, 2006; Kallbekken \& Sælen, 2001). In this way, the perceived trustworthiness of government constitutes an important decision heuristic, which allows people to accept or reject policies in situations where cognitive evaluations may be complex or mental resources are limited (Cummings, 2014; Finucane, Alhakami, Slovic, \& Johnson, 2000). For example, in situations where governments are deemed untrustworthy, voters might outright reject new policies instead of engaging in more deliberate evaluations. Thus, we hypothesise that trust has a positive influence on policy acceptance (H1, see Figure 1). 


\section{The mediating role of emotions}

Dual process models such as the Elaboration-Likelihood Model (Petty \& Cacioppo, 1986) and Dual-Process Theory (Epstein, 1994) suggest that people process information either centrally via conscious reasoning and deliberate evaluations, or peripherally, implying that external cues are used to process information, and to form attitudes. This suggests that trust can either influence policy acceptance via expected costs and benefits or via their affective responses. Likewise, Eagly and Chaiken (2007), argued that people's evaluations of objects and events are typically based on affective and cognitive components, that is: "evaluations encompass aspects of beliefs and thoughts, feelings and emotions, and [that].... None of these reactions need be concisely experienced by the holder of an attitude, although they may be conscious" (p. 583). This implies that trust can influence policy acceptance also indirectly via people's affective responses as well as via expected costs-benefit evaluation.

Such a mediation model is more likely when situations are new, unknown and unclear (Bratspies, 2009; Earle \& Cvetkovich, 1995; Midden \& Huijts, 2009), since people may not have sufficient knowledge or arguments available to make an informed decision, triggering affect-based judgments of activities that can lead to negative/positive outcomes (Poortinga \& Pidgeon, 2005). This was the context around the Irish water charges before they were implemented, as the design of the policy was largely unclear until a month before the implementation. In such situations, the influence of trust on policy acceptance was shown to be mediated by people's emotional reactions ${ }^{1}$ as well as cognitive costs and benefits

\footnotetext{
${ }^{1}$ Affect is defined as a general evaluation of a stimulus ranging from good to bad or from positive to negative (Visschers \& Siegrist, 2008). Emotions on the other hand (also called discrete emotions, e.g., Smith \& Leiserowitz, 2014) refer to specific feelings (e.g., sadness, anger, excitement). Concretely, emotions have been described as " a complex state of feeling that results in psychophysiological state that influences thoughts and behaviour" (Myers, 2004, p.500). Emotions are intense, short-lived, and usually have a definite cause and clear cognitive content (Forgas, 1992). This is in contrast to moods, which are not always caused by a specific stimulus (Finucane et al., 2000). In many studies, affect and emotions are used interchangeably (e.g., Huijts \& van Wee, 2015; Midden \& Huijts, 2009). In this study, when we refer to emotions we focus on integral emotions, which constitute feelings that arise from a decision at hand, and which strongly and routinely shapes
} 
evaluations (e.g., Midden \& Huijts, 2009; Siegrist, Cousin, Kastenholz, \& Wiek, 2007; Truelove, 2012; Zajonc, 1980).

Lack of trust in the government has a negative influence on people's emotional responses, and can trigger emotions such as anger or fear (e.g., Gray \& Ropeik, 2002; Peters, Burraston, \& Mertz, 2004). Slovic (1999) highlights that trust is an important factor, which can reduce negative emotions and help to boost positive emotional appraisals. For example, research shows that trust in government and industry influenced specific feelings (e.g., worries, annoyance, and satisfaction) towards the introduction of $\mathrm{CO}_{2}$ storage technologies, which subsequently impacted acceptance (Midden \& Huijts, 2009). Likewise, in the context of hydrogen fuel station acceptance, trust in the municipality was negatively associated with emotions such as powerlessness, stress or fear, while trust in the industry was positively associated with emotions like pride or calmness (Huijts, Molin, \& van Wee, 2014).

Emotions in turn are important determinants of policy acceptance. For instance, specific negative feelings about global warming have been shown to influence individual support for different national policies in regard to environmental problems (Leiserowitz, 2006). In addition, Tausch and Becker (2013) study shows that students who felt angry about tuition fees, were more likely to engage in collective action. Similarly results were found by van Zomeren, Spears, Fischer and Leach (2004) regarding the role of specific emotions (in particular anger) and its effects on collective action.

An affective reaction is particularly likely under conditions of high self-relevance. That is, in situations which may involve positive or negative consequences for individuals, the emotional reaction is stronger than in situations with low personal relevance (Lazarus, 1994). In the context of the Irish water charges, an affective reaction is likely because of the decision-making (Greene \& Haidt, 2002). 
consequences (e.g., financial) of the policy for the Irish people. Hence, we propose that the influence of trust on policy acceptance is mediated by positive and negative emotions towards the policy (H2a,b; H3a,b see Figure 1).

\section{The mediating role of expected cost-benefit evaluations}

Further, we hypothesise that people's (dis)trust in the government influences their evaluations of expected costs and benefits (Slovic, Finucane, Peters, \& MacGregor, 2004). Several researchers in risk management have proposed a model called the "causal chain model of trust", which suggests that trust does only indirectly influence acceptance (Siegrist, 1999, 2000). Specifically, trust has been shown to indirectly impact acceptance through expected costs and benefits (Bronfman, Jiménez, Arévalo, \& Cifuentes, 2012; Siegrist et al., 2003; Visschers \& Siegrist, 2014). Importantly, this mediated effect was much stronger than the direct influence of trust on acceptance, which in some cases was small or even nonsignificant (e.g., Greenberg, 2009; Greenberg \& Truelove, 2011). The findings show that people who trusted the public institutions responsible for regulatory issues (e.g., nuclear power station plant or carbon dioxide capture and storage), associated less risks and more benefits with the implementation of these technologies and/or policies than people who did not (Bronfman, et al., 2012; Siegrist et al., 2003; Visschers \& Siegrist, 2014).

Furthermore, when people evaluate the outcome of an object (e.g., the introduction of a new policy), it can be judged favourably, neutral or unfavourably, referring to the valence of a belief (Schuitema et al., 2010a). Theories such as the Expectancy Theory (Klandermans, 1984; Vroom, 1964) or Theory of Planned Behaviour (Ajzen, 1991) assume that choices or attitudes result from evaluating expected costs and benefits, and that people will choose options with the highest perceived gains. Traditionally, researchers have argued that acceptance of certain policies depends on people's evaluations of expected costs and benefits (Lubell, Vedlitz, Zahran, \& Alston, 2006), also referred to as 'effectiveness' of the measure 
(e.g., Kallbekken \& Sælen, 2011). Unsurprisingly, people are more likely to resist the introduction of a new policy when they associate higher costs or risks with the potential outcomes of this policy (de Groot \& Steg, 2010; Nancarrow, Porter, \& Leviston, 2010; Schuitema et al., 2010a; Stoutenborough et al., 2013). For instance, one may believe that water charges will lead to higher water prices (i.e., negative outcome), and/or that water supply quality will improve as a result of the policy (i.e., positive outcome). Thus, acceptance of a policy will depend on people's beliefs about the personal as well as the collective positive/negative outcomes of these policies (Bamberg \& Rölle, 2003; Perlaviciute, \& Steg, 2014). In sum, we hypothesise that the influence of trust on policy acceptance is mediated by people's beliefs about benefits and costs associated with the policy (H4a,b; H5a,b, see Figure 1).

\section{The influence of emotions on cognitive evaluations}

Recent findings in psychology suggest that people's cognitive deliberations are often influenced by affect and emotions (Lerner, Li, Valdesolo \& Kassam, 2015; Truelove, 2012; Zajonc, 1980). Empirical evidence supports the idea that beliefs about negative and positive outcomes, which are largely cognitive evaluations, are steered by emotions (Lerner et al, 2015). For instance, 'dread' has been shown to strongly influence people's negative expected outcomes across different contexts (Fischhoff, Slovic, Lichtenstein, Read, \& Combs, 1978), while 'fear' and 'anger' seem to play important roles in people's perceptions of public hazards such as radiation, genetically modified foods, and terrorism (Peters et al., 2004). Also, 'disgust' has been shown to influence people's assessment of food safety (Nauta et al., 2008). In other words, emotions influence the decision-making process by influencing what people think (e.g., Lerner, et al., 2015; Renshon \& Lerner, 2012). This idea has been conceptualized in theories such as the Appraisal-Tendency Framework (Lerner \& Keltner, 2000, 2001) and Functional Theory of Emotion (Izard, 1993), which links specific emotions 
to specific judgment and decision-making outcomes:

“(...) an object or event in the environment is perceived and appraised for its relevance for personal well-being. Particular patterns of appraisals then lead to certain states of action readiness, the awareness of which is the subjective emotional experience. These action tendencies are associated with physiological changes that together influence future perceptions, cognitions, and behaviours in accordance with the goal set by the action tendency" (Nabi, 2003, p. 226).

Thus, one can expect that positive emotions lead to more positive outcome evaluations, whereas negative emotions result in more negative outcome evaluations (Learmonth \& Humphreys, 2011; Lindebaum \& Jordan, 2012) (H6a-d, see Figure 1).

$>$ insert Figure 1 about here<

In sum, we aim to understand the role of trust and emotions for the public acceptance of Irish water charges. Specifically, we aim to test a mediation model (see Figure 1) in which trust in the government influences public acceptance via people's emotions and expected cost-benefit evaluations of the policy. Secondly, assuming that emotions are an important factor, we investigate which specific emotions are important in case of the public acceptance of the Irish water charges.

\section{Method}

\section{Procedure and participants}

An online-survey $(\mathrm{N}=505)$ was conducted amongst adults $(18+)$ who had been living in the Republic of Ireland for at least three years as of October 2015. Participants were invited to participate once and no reminders were sent. The data was collected over a six-week period. The questionnaire started with general instructions for the respondents. These were carefully drafted so that participants did not realise that the survey was about water charges, thus limiting self-selection bias. In the first part of the questionnaire, we captured key demographic variables and measured people's general trust in the current Irish government. It 
is important to note that up until this point in the survey, respondents were not aware that the Irish water charges were the focal topic of this survey. Hence, trust in the government constitutes a general measure which is not related to or biased by the water charges.

Next, a brief and factual description of the water charges was given to ensure that all respondents understood what was meant by "water charges". This was followed by measures of the focal constructs, including emotions, expected costs and benefits, subjective knowledge and acceptance of water charges. Finally, respondents were asked about sociodemographic factors.

The convenience sample consisted of academic and non-academic staff of two major Irish Universities $(\mathrm{N}=505)$. It is important to note that our sample is not representative of the Irish population. The average age of the sample population was 44 years, and it included a slight overrepresentation of female respondents $(58 \%)$. The educational level is higher than that of the general population $(87.1 \%$ of participants had a third-level degree of equivalent) and the sample was slightly skewed towards people living in urban areas $(66.7 \%)$.

\section{Measures}

All focal constructs of this study were measured via five-point Likert scales (see Table 1 for an overview of the descriptive statistics of all the variables).

$>$ Insert Table 1 about here<

Policy acceptance was adapted from Stern (2000) and de Groot and Steg (2006) to the specific context of water charges and included the following questions: How often do you sign petitions against the water charges? (1 - never/ 5- always); What is your general position if discussing water charges with other people like friends and family? (1 - strongly in favour/ 5- strongly against); When did you sign up for up for the water charges? (1 - 
immediately/ 5 - not yet); I have accepted the water charge (1 - totally disagree/ 5 - totally agree); I agree with the water charge (1 - totally disagree/ 5 - totally agree).

Measures for expected costs and benefits were based on Ajzen's (1991) measurement of beliefs, capturing both the probability and importance of potential outcomes of costs and benefits of the water charges. In order to elicit context-specific costs and benefits in regard to water charges, face-to-face interviews $(n=8)$ were conducted prior to the survey. In terms of costs, people assessed the likelihood that the introduction of water charges will result in unnecessary bureaucracy and red tape; higher prices for water; reduced households budget; and privatization of water ( 1 - not probable/ 5 - very probable) and importance of these consequences $(1-$ not at all important/ 5 - very important $)$. Likewise, people evaluated the probability that water charges would result in benefits, including improved water infrastructure; improved water safety; better water quality; and increased awareness for water scarcity. Importantly, exploratory factor analysis using principal component analysis (PCA) with varimax rotation confirmed that expected costs and benefits are indeed two distinct factors. The scores for expected costs and benefits were calculated by multiplying the score on probability and importance of consequences.

We also measured people's emotions towards the water charges, based on measures from Sjöberg (2007), Truelove (2012), and Visschers and Siegrist (2014). Respondents were asked to indicate to what extent certain emotions best described their personal feelings towards the introduction of water charges ( 1 - does not describe/ 5 - fully describes). The six negative emotions were angry; worried; deceived; frustrated; irritated; and hostile. Conversely, positive emotions were measured using the terms optimistic; enthusiastic; interested; satisfied; and relaxed. Again, factor analysis confirmed a two-factor structure, suggesting that negative and positive emotions are distinct constructs. 
The independent variable trust in the government was measured with five items that were adopted from Poortinga and Pidgeon (2006). Participants indicated to what extent they agreed with statements $(1-$ totally disagree/ 5 - totally agree) including the Irish government is generally doing a good job; acts in the public interest; is competent enough; listens to what ordinary people think; and in general I trust the Irish government (1 - totally disagree/ 5 totally agree).

\section{Results}

\section{Confirmatory Factor Analysis}

To test the validity of our model (Figure 1), we analysed the data via a two-step procedure in EQS.6.1. First, we analysed the convergent validity via confirmatory factor analysis (CFA) using robust maximum likelihood estimations (see Table 2). Due to low and/or cross loadings we deleted two items from the emotion scale (i.e. worried and interested), as well as two items from the policy acceptance scale (i.e. How often do you sign petitions against the water charges? and When did you sign up for up for the water charges?). After the initial purification of the scales, the measurement model indicated a good model, fit with a Root Mean Square Error of Approximation (RMSEA) of 0.058 [90\% CI = 0.051-0.062]; SatorraBentler Scaled Chi-square $\left(\right.$ SB- $\left.\chi^{2}\right)=677.53 ; \mathrm{df}=260 ; \mathrm{p}<.001$; Normed $\chi^{2}=2.60$; Normed Fit Index $(\mathrm{NFI})=0.941$; Comparative Fit Index $(\mathrm{CFI})=0.949$. Composite Reliability Index (CRI) and the Average Variance Extracted (AVE) exceed the minimum value of 0.70 and 0.50 , respectively, for all constructs. Secondly, we analysed the discriminant validity of the model. Results showed that the confidence interval for the correlations between pairs of factors are all below one, while the AVE for each factor exceeded the squared correlation between each pair of factors, thus providing additional evidence for the discriminant validity of the constructs (Table 3). 
$>$ Insert Table 2 about here<

$>$ Insert Table 3 about here<

\section{Structural Relationships}

Once we checked the psychometric properties of our model, we tested the proposed relationships of the model via Structural Equation Modelling (SEM). Figure 2 shows a graphic representation of the path coefficients $(B)$ and the explained variance $\left(\mathrm{R}^{2}\right.$ values) of the dependent variables. Overall, the results indicated an acceptable fit between the data and the hypothesised model $\left(\mathrm{RMSEA}=0.057[90 \% \mathrm{CI}=0.051-0.062], \mathrm{SB}-\chi^{2}=677.534, \mathrm{df}=\right.$ $261 ; \mathrm{p}<.001 ;$ Normed $\left.\chi^{2}=2.59 ; \mathrm{NFI}=0.920 ; \mathrm{CFI}=0.941\right)$. Importantly, with the exception of the direct relationship between trust and policy acceptance, as well as trust and expected costs, all hypothesised relationships in the model were supported by the data. Overall, a large amount of variance $\left(\mathrm{R}^{2}=0.82\right)$ in policy acceptance was explained. All path coefficients for the indirect and direct relationships are summarised in Table 4 and presented in Figure 2.

\section{$>$ Insert Figure 2 about here<}

Findings show that the direct influence of trust on policy acceptance was not significant $(B=$ $0.06, \mathrm{p}>0.10$, rejecting $\mathrm{H} 1$ ) when emotions and expected costs and benefits were introduced in the model, suggesting that the influence of trust on policy acceptance is mediated by emotions and expected costs and benefit evaluations (indirect effect $\beta=0.53, \mathrm{p}<0.01$ ).

In addition, results show that the level of trust in government directly influenced negative and positive emotions towards water charge $(\beta=-0.57, \mathrm{p}<0.01 ; \beta=0.45, \mathrm{p}<0.01$ respectively $)$, providing strong support for $\mathrm{H} 2 \mathrm{a}$ and $\mathrm{H} 2 \mathrm{~b}$. Moreover, the direct relationship between negative and positive emotions and policy acceptance was significant $(\beta=-0.46, p<0.01 ; \beta=$ $0.28, \mathrm{p}<0.01$ respectively), which supports $\mathrm{H} 3 \mathrm{a}$ and $\mathrm{H} 3 \mathrm{~b}$. These results suggest that both 
negative and positive emotions play an important mediating role between trust and policy acceptance (partial indirect effect, negative emotions: $\beta=-0.57 *-0.46=0.26$ and positive emotions $\beta=0.45^{*} 0.28=0.13$ ).

There are substantial differences in the role played by both cognitive evaluations (expected costs and benefits) in the model. Results suggest that trust in the government has a direct influence only on expected benefits $(\beta=0.20, \mathrm{p}<0.01$, supporting $\mathrm{H} 4 \mathrm{~b})$ but not on expected costs $(\beta=-0.01, \mathrm{p}>0.10$, rejecting H4a). Furthermore, the direct effects of these cognitive variables on policy acceptance were significant as expected $(\beta=-0.08, p<0.01$ and $\beta=0.24$, $\mathrm{p}<0.01$ ), which supports $\mathrm{H} 5 \mathrm{a}$ and $\mathrm{H} 5 \mathrm{~b}$ respectively. The joint analysis of these results shows that the relationship between trust in government and policy acceptance is only mediated by the expected benefits of the policy. However, this mediating effect is small in magnitude (partial indirect effect, expected benefits: $\beta=0.20 * 0.24=0.05$ ).

Finally, regarding the influence of emotions on cognitive evaluations, results indicated that emotions are important antecedents of cost-benefit evaluations. It needs to be noted that the direct effect of negative emotions on expected costs is much stronger $(B=0.49, \mathrm{p}<0.01)$ than the direct effect of positive emotions $(B=-0.17, \mathrm{p}<0.01)$. However, the direct effect of positive and negative emotions on expected benefits were of similar magnitude (negative $\beta=$ $-0.27, \mathrm{p}<0.01$ and positive $0.30, \mathrm{p}<0.01)$. While the findings provide strong support for H6a$\mathrm{d}$, the magnitude of these indirect effects on policy acceptance was relatively small and accounted for approximately $20 \%$ of the total effect in both cases.

>Insert Table 4 about here<

\section{The relative influence of specific emotions on policy acceptance}

While the above findings provide strong evidence for the direct and indirect influence of trust and emotions on policy acceptance, we wanted to further investigate which specific emotions 
had the strongest influence on policy acceptance. Hence, we conducted a separate linear OLS regression analysis ${ }^{2}$, unbundling the positive/negative emotion constructs and treating each emotion-item as an independent variable ${ }^{3}$ (see Table 5). As expected, results confirm our previous findings in that emotions have high explanatory power, explaining $67 \%$ of variance (adjusted $\left.\mathrm{R}^{2}\right)$ in the acceptance of water charges $(\mathrm{F}(9,495)=111.9 ; \mathrm{p}<0.01)$. There were no collinearity problems among the independent variables (emotions) since the Condition Index (13.78) is below the recommend value of 20-30 (Belsley, 1982; Belsley, Kuh, \& Welsch, 1980). VIF and Tolerance indicators also show acceptable levels (Hair, Anderson, Tatham, \& Black, 1995; Tabachnick \& Fidell, 2001).

With the exception of 'irritated' $(p>0.05)$, all emotions had a significant influence on the acceptance of water charges. Specifically, findings show that the negative emotion 'anger' was the strongest predictor of policy acceptance $(\beta=-0.36, p<0.01)$, followed by 'hostility' $(\beta=-0.20, p<0.01)$. For positive emotions, 'relaxation' $(\beta=0.12, p<0.01)$ and 'enthusiasm' $(\beta=0.12, p<0.01)$ were the dominant positive emotions for policy acceptance.

\section{$>$ Insert Table 5 about here<}

\section{Discussion and conclusion}

Many policies, when first introduced, can evoke strong emotional reactions from the public, and the water charges in Ireland were no exception (Power, Haynes, \& Devereux, 2015). Low acceptance levels can be particularly problematic in situations where policies aim to protect and safeguard the collective good like environmental or social policies (Gärling \&

\footnotetext{
${ }^{2}$ Note that "worried" and "interested" emotions were not included in this regression analysis since they were eliminated during the CFA analysis and they are not part of the emotion constructs in the main model.

3 To test the robustness of the results, an alternative model controlling by trust, cost and benefits has been performed. The estimated results from this model show stable coefficients (7 out of 9 coefficients), except for "irritated" and "optimistic", which become non-significant. In addition, this model also shows a similar explanatory power (approx. Adjusted $\mathrm{R}^{2} 71 \%$ ). Due to length restrictions only the baseline model is included in the text, the alternative estimations are available upon request. SEM has also been used to estimate the relationship between negative and positive emotions and acceptance of the policy showing similar results.
} 
Schuitema, 2007; Schuitema et al., 2010b). While most studies to date have focused on cognitive factors or moral motivations in policy acceptance, research has paid relatively little attention to affective variables, including emotions and trust. This is despite a recent surge of psychological research, which highlights the critical role emotions play in decision-making (Lerner et al., 2015). Addressing this paucity in the context of the Irish water charges, we find that trust and emotions are key predictors of the public acceptance of water charges in Ireland.

In contrast to $\mathrm{H} 1$ and previous studies, we find that trust has no direct influence on policy acceptance (Harring \& Jagers, 2013; Kallbekken \& Sælen, 2011; Kyselá, 2016). However, in line with our hypotheses, trust has a strong indirect effect on policy acceptance, which is mediated via emotions and, to a lesser extent, via the expected costs and benefits of the policy. This indirect effect of trust on policy acceptance indicates that general trust in the government - which we measured generally, hence unrelated to the water charges - can influence affective and cognitive responses to specific policies. This is an important finding, which implies that establishing general trust in key authorities is an important antecedent that influences people's evaluations, and subsequent acceptance of specific policies.

Further, we find that public acceptance is largely steered by affective responses to the water charges since trust influences policy acceptance via their emotions (H2, H3). In addition, there was also a mediation effect of the expected benefits (H4b, H5b), although the effect was much weaker. We thus conclude that emotions played a much greater role in the acceptance of the water charges than the expected costs/benefits, and that the affective path was the main driver of the policy evaluations (Cummings, 2014). The results further indicate that the evaluation of costs and benefits seem less important for policy acceptance than is often assumed in the literature (e.g., de Borger \& Proost, 2010). These findings also hold important policy implications. For example, communication strategies aiming to win the public's 
support for specific policies often tend to focus on rational arguments for certain policies. Yet, our results suggest that communication messages, which positively influence people's emotional states are more likely to change policy acceptance than simply highlighting the benefits of a new policy.

Further, results show that negative emotions have a larger direct effect on policy acceptance (H3a) than positive emotions (H3b). This is in line with other studies, which investigated public policy acceptance in different contexts, although the type of emotion has been shown to vary and appears to be dependent on the specific context (e.g., Midden \& Huijts, 2009; Perlaviciute et al., 2017). In case of the Irish water charges, feelings of anger were the most important determinant of policy acceptance. However, in the debate about earthquakes induced by gas production in the Netherlands (Perlaviciute et al., 2017), feelings of powerlessness were dominating.

Regarding the mediating role of cognitive evaluations it is important to highlight that our results partially support the "causal model of trust" (Siegrist, 1999, 2000). This model assumes that trust in regulations indirectly influences acceptance via expected costs and benefits (see also Bearth, Cousin, \& Siegrist, 2014; Huijts et al, 2014). However, our findings do not support a direct relationship between trust and expected costs (H4a). Moreover, we find that expected benefits have a greater direct influence on policy acceptance (H5b), compared to expected costs (H5a). This suggests that despite the strong influence of negative emotions, cognitively people associate more benefits with water charges (e.g., improved water quality) than potential negative outcomes. These results are consistent with previous studies, which suggest that benefits are more relevant than costs or risks in people's decisionmaking (e.g., Esaiasson, Persson, Gilljam, \& Lindholm, 2016; Siegrist, 1999; Siegrist et al, 2007). 
As hypothesised, our findings also suggest that when individuals report (positive) negative emotions towards the policy, they also associate more (less) costs and less (more) benefits with it (H6). This is in line with previous findings, which suggest that cognitive evaluations are rooted in people's affective responses (Lerner et al, 2015; Truelove, 2012; Zajonc, 1980). In other words, findings show that the evaluation of expected costs and benefits is a justification of how people feel about a policy. Again, this suggests that the affective pathway is the key driver of policy acceptance.

Finally, scholars have argued that positive and negative emotions are different constructs with different valences, rather than polar opposites (Finucane et al., 2000; Watson, Clark, \& Telleg, 1988). This implies that positive and negative emotions may influence public acceptance in different ways. There are some indications in our study that support this idea. For example, it appears that the expected costs are more strongly influenced by negative compared to positive emotions, whereas the expected benefits are equally influenced by negative and positive emotions. This could imply, as some authors suggest, that emotions of the same valence may have different effects on cognitive evaluation processing (e.g., Kühne, 2012; Griskevicius, Shiota, \& Neufeld, 2010). Future research is needed to examine this hypothesis in greater detail.

\section{Limitations and future research}

While this study presents initial evidence for the role of trust and emotions in policy acceptance, it has several limitations which provide fruitful avenues for further research. Firstly, the results must be interpreted with care, as we cannot draw fully generalizable conclusions about causal relationships based on our cross-sectional dataset. Further systematic research on these conclusions is needed to collate more evidence about how affective and cognitive components influence policy acceptance. In addition, it must be noted that our sample was not representative of the Irish population and that we had a strong 
overrepresentation of people with a higher social-economic status. However, studies report that most socio-demographic factors, including social class, have little influence on people's attitude towards the water charges (RedC., 2014). Hence, it is reasonable to assume that our sample characterises had little or no influence on our results.

In addition, it is important to see our study in the broader context of a larger public debate. We focused on specific factors that are important in the context of this debate. However, other factors may have played a role as well. For example, when looking at the content and the nature of the debates it is likely that other issues, such as perceptions of fairness, social norms, or media coverage may have also influenced policy acceptance. For example, Hearne (2015) argues that people's emotional responses regarding the water charges are rooted in the cumulative impact of the recession as well as the imposed austerity measures had on people's lives. While acknowledging that context and other factors are important for the formation of the public acceptance of water charges, we also note that our study highlights that specially trust and emotions are one of those important factors.

In conclusion, our findings present evidence that trust and emotions are key determinants of policy acceptance. Our results add to a growing body of literature that has explored the role of emotions and trust in areas such as technology acceptance (e.g., Midden and Huits, 2009). Specifically, we find that the influence of trust on policy acceptance is mediated by people's emotional appraisals and cognitive evaluations of the policy. Further, our findings add to a growing body of research, which shows that emotions are important antecedents of people's rational evaluations of policies.

Our findings also have implications for how policy makers communicate with the public. Indeed, our findings suggest that negative emotions and lack of trust can have detrimental impacts on "cognitively-framed" discussions about new policies. Thus, policy makers should be wary of the potentially over-powering role of people's emotions (over rational cognitive 
arguments) when it comes to policy acceptance. In addition, it seems more useful if policy makers focus on highlighting and communicating benefits of policies, instead of aiming to reduce public costs associated with a policy. Finally, a general level of trust in governing bodies is an important determinant of people's affective and cognitive appraisal as well as their subsequent acceptance of specific policies. Policy makers would thus do well to remember that trust is difficult to gain, but is easily lost (Slovic, Flynn, \& Layman, 1991). 


\section{REFERENCES}

Adaman, F., Karali, N., Kumbaroğlu, G., Or, I., Özkaynak, B., \& Zenginobuza, U. (2011). What determines urban households' willigness to pay for $\mathrm{CO} 2$ emission reduction in Turkey: A contingent valuation survey. Energy Policy, 39,689-698. doi:10.1016/j.enpol.2010.10.042

Ajzen, I. (1991). Theory of planned behavior. Organizational Behavior and Human Decision Processes, 50, 179-211. doi:10.1016/0749-5978(91)90020-T

Bamberg, S., \& Rölle, D. (2003). Determinants of people's acceptability of pricing measures: replication and extension of a causal model. In J. Schade, \& B. Schlag (Eds.), Acceptability of Transport Pricing Strategies (pp. 235-248). Oxford: Elsevier Science.

Bearth, A., Cousin, M. E., \& Siegrist, M. (2014). The consumer's perception of artificial food additives: Influences on acceptance, risk and benefit perceptions. Food Quality and Preference, 38,14-23. doi:10.1016/j.foodqual.2014.05.008

Belsley, D.A. (1982). Assessing the presence of harmful collinearity and other forms of weak data through a test for signal-to-noise. Journal of Econometrics, 20(2), 211-253. doi: $10.1016 / 0304-4076(82) 90020-3$

Belsley, D.A., Kuh, E., \& Welsch, R.E. (1980). Regression Diagnostics. New York: John Wiley and Sons.

Bratspies, R.M. (2009). Regulatory trust. Arizona Law Review, 51, 575-631.

Bronfman, N. C., Jiménez, R. B., Arévalo, P. C., \& Cifuentes, L. A. (2012). Understanding social acceptance of electricity generation sources. Energy Policy, 46, 246-252. doi: 10.1016/j.enpol.2012.03.057 
Cummings, L. (2014). The "trust" heuristic: Arguments from authority in public health. Health Communication, 29(10), 1043-1056. doi:10.1080/10410236.2013.831685

De Borger, B., \& Proost, S. A. (2010). A political economy model of road pricing. Journal of Urban Economics, 71(1), 79-92. doi:10.2139/ssrn.1633425

De Groot, J., \& Steg, L. (2006). Impact of transport pricing on quality of life, acceptability, and intentions to reduce car use: An exploratory study in five European countries. Journal of Transport Geography, 14(6),463-470. doi:10.1016/j.jtrangeo.2006.02.011

De Groot, J., \& Steg, L. (2010). Morality and nuclear energy: perceptions of risks and benefits, personal norms, and willingness to take action related to nuclear energy. Risk Analysis, 30(9), 1363-1373. doi:10.1111/j.1539-6924.2010.01419.x

De Groot, J., Steg, L., \& Poortinga, W. (2013). Values, perceived risks and benefits, and acceptability of nuclear energy. Risk Analysis,33(2), 307-317. doi:10.1111/j.15396924.2012.01845.x

Eagly, A. H., \& Chaiken, S. (2007). The advantages of an inclusive definition of attitude. Social Cognition, 25(5), 582-602.

Earle, T. C., \& Cvetkovich, G. T. (1995). Social Trust. Towards a Cosmopolitan Society. London: Praeger.

Epstein, S. (1994). Integration of the cognitive and the psychodynamic unconscious. American Psychologist, 49(8), 709-724.doi:10.1037/0003-066X.49.8.709

Esaiasson, P., Persson, M., Gilljam, M., \& Lindholm, T. (2016). Reconsidering the role of procedures for decision acceptance. British Journal of Political Science, 1-24. doi:10.1017/S0007123416000508 
Finucane, M. L., Alhakami, A., Slovic, P., \& Johnson, S. (2000). The affect heuristic in judgments of risks and benefits. Journal of Behavioral Decision Making, 13, 1-17. Retrieved from https://search.proquest.com/docview/214694653?accountid=17192

Fischhoff, B., Slovic, P., Lichtenstein, S., Read, S., \& Combs, B. (1978). How safe is safe enough? A psychometric study of attitudes towards technological risks and benefits. Policy Sciences, 9, 127-152. doi:10.1007/BF00143739

Forgas, J. P. (1992). Affect in social judgments and decisions: A multiprocess model. In Zanna, M. (Ed.). Advances in Experimental Social Psychology (pp. 227-275). San Diego, CA: Academic Press.

Gärling, T., \& Schuitema, G. (2007). Travel demand management targeting reduced private car use: Effectiveness, public acceptability and political feasibility. Journal of Social Issues, 63, 139-153. doi:10.1111/j.1540-4560.2007.00500.x

Gray, G. M., \& Ropeik, D. P. (2002) Dealing with the dangers of fear: the role of risk communication. Health Affairs, 21(6),106-116. doi:10.1377/hlthaff.21.6.106

Greenberg, M. (2009). Energy sources, public policy, and public preferences: Analysis of US national and site-specific data. Energy Policy, 37, 3242-3249. doi: 10.1016/j.enpol.2009.04.020

Greenberg, M., \& Truelove, H. B. (2011). Energy choices and risk beliefs: Is it just global warming and fear of a nuclear power plant accident? Risk Analysis, 31, 819-831. doi: 10.1111/j.1539-6924.2010.01535.x

Greene, J., \& Haidt, J. (2002). How (and where) does moral judgment work? Trends in Cognitive Sciences, 6(12), 517-523. doi:10.1016/S1364-6613(02)02011-9 
Griskevicius, V., Shiota, M. N., \& Neufeld, S. L. (2010). Influence of different positive emotions on persuasion processing: A functional evolutionary approach. Emotion, 10(2), 190-206. doi: 10.1037/a0018421

Hair, J. F. Jr., Anderson, R. E., Tatham, R. L. \& Black, W. C. (1995). Multivariate Data Analysis (3rd ed). New York: Macmillan.

Hamma, H., \& Jagers, S. C. (2006). Can trust in politicians explain individuals' support for climate policy? The case of $\mathrm{CO} 2$ tax. Climate Policy, 5, 613-625. doi:10.1080/14693062.2006.9685582

Harring, N., \& Jagers, S. C. (2013). Should we trust in values? Explaining public support for pro-environmental taxes. Sustainability, 5, 210-227. doi:10.3390/su5010210

Hearne, R. (2015). The Irish water war, austerity and the 'Risen people'. Department of Geography, Maynooth University, 2015. Retrieved from:https://www.maynoothuniversity.ie/sites/default/files/assets/document/TheIrishWate $\underline{\text { rwar_0.pdf }}$

Holland, K. (2014). Over 50,000 flood on to streets of capital. The Irish Times, 2014, 13 October. Retrieved from: http://www.pressreader.com/ireland/the-irish-times/20141013

Howes, M., Wortley, L., Potts, R., Dedekorkut-Howes, A., Serrao-Neumann, S., Davidson, J.,... \& Nunn, P. (2017). Environmental sustainability: A case of policy implementation failure? .Sustainability, 9(2), 165. doi:10.3390/su9020165

Huijts, N. M., Molin, E. J., \& van Wee, B. (2014). Hydrogen fuel station acceptance: A structural equation model based on the technology acceptance framework. Journal of Environmental Psychology, 238, 153-166. doi:10.1016/j.jenvp.2014.01.008 
Huijts, N., \& van Wee, B. (2015). The evaluation of hydrogen fuel stations by citizens: The interrelated effects of socio-demographic, spatial and psychological variables. International Journal of Hydrogen Energy, 40(33), 10367-10381. doi:10.1016/j.ijhydene.2015.06.131

Irish Water (2016). Irish Water confirms $61 \%$ of customers are now paying water charges. Retrieved from: https://www.water.ie/news/irish-water-confirms-61-o/

Izard, C. E. (1993). Organizational and motivational functions of discrete emotions. In M. Lewis \& J. M. Haviland (Eds.), Handbook of Emotions (pp. 631-641). New York: Guilford.

Kallbekken, S., \&Sælen, H. (2011). Public acceptance for environmental taxes: self-interest, environmental and distributional concerns. Energy Policy, 39, 2966-2973. doi:10.1016/j.enpol.2011.03.006

Kasperson, J. X., Kasperson, R. E., Pidgeon, N., \& Slovic, P. (2003). The social amplification of risk: Assessing fifteen years of research and theory. In N. Pidgeon, R. E. Kasperson, \& P. Slovic (Eds.), The Social Amplification of Risk (pp.13-46). Cambridge, England: Cambridge University Press.

Klandermans, B. (1984). Mobilization and participation: Social-psychological expansion of resource mobilization theory. American Sociological Review, 49(5), 583-600. Retrieved from: http://www.jstor.org/stable/2095417

Kühne, R. (2012). Media-induced affects and opinion formation: How related and unrelated affects influence political opinions. Living Reviews in Democracy, 3. Retrieved from: https://www.Ird.ethz.ch/index.php/lrd/article/view/31/54 
Kyselá, E. (2016). Acceptability of environmental policies in the Czech Republic: A comparison with willingness to make economic sacrifices. Social Studies, 12(3), 179-198. Retrieved from: https://journals.muni.cz/socialni_studia/article/view/6076

Lazarus, R. (1994). Universal antecedents of the emotions. In P. Ekman \& R. J. Davidson (Eds.), The Nature of Emotions (pp. 163-171). New York: Oxford University Press.

Learmonth, M., \& Humphreys, M. (2011). Blind spots in Dutton, Roberts and Bednar's'Pathways for positive identity construction at work': 'You've got to accentuate the positive, eliminate the negative'. Academy of Management Review, 36(2), 424- 427. doi:10.5465/amr.2010.0153

Leiserowitz, A. (2006). Climate change risk perception and policy preferences: The role of affect, imagery, and values. Climatic Change, 77(1), 45-72. doi:10.1007/s10584-0069059-9

Lerner, J. S., \& Keltner, D. (2000). Beyond valence: Toward a model of emotion-specific influences on judgement and choice. Cognition \& Emotion, 14(4), 473-493. doi:10.1080/026999300402763

Lerner, J. S., \& Keltner, D. (2001). Fear, anger, and risk. Journal of Personality and Social Psychology, 81(1), 146. doi:10.1037/0022-3514.81.1.146

Lerner, J. S., Li, Y., Valdesolo, P., \& Kassam, K. S. (2015). Emotion and decision making. Annual Review of Psychology, 66, 799-823. doi:10.1146/annurev-psych-010213-115043

Lewis, J. D., Weigert, A. (1985). Trust as a social reality. Social Forces, 63(4), 967-985. doi:10.1093/sf/63.4.967 
Lindebaum, D., \& Jordan, P. J. (2012). Positive emotions, negative emotions, or utility of discrete emotions? Journal of Organizational Behavior, 33(7), 1027-1030. doi:10.1002/job.1819

Lopez-Navarro, M. A., Llorens-Monzonis, J., \& Tortosa-Edo, V. (2013). The effect of social trust on citizens' health risk perception in the context of a petrochemical industrial complex. International Journal of Environmental Research and Public Health, 10, 399416. doi:10.3390/ijerph10010399

Lubell, M., Vedlitz, A., Zahran, S., \& Alston, L. T. (2006). Collective action, environmental activism, and air quality policy. Political Research Quarterly, 59(1), 149-160. doi:10.1177/106591290605900113

McGee, H. (2012a). On tap: A short history of Irish water charges. The Irish Times, 2012, April 21. Retrieved from: http://www.seswater.ie/on-tap-a-short-history-of-irish-watercharges/

McGee, H. (2012b). What's Ireland's problem with water charges? The Irish Times, 2012, April 21. Retrieved from: http://www.irishtimes.com/news/what-s-ireland-s-problemwith-water-charges-1.506087

McGee, H., \& McMahon, A. (2014). Protest organisers to step up their campaign for water charges abolition. The Irish Times, 2014, 11 December. Retrieved from: http://www.irishtimes.com/news/environment/protest-organisers-to-step-up-theircampaign-for-water-charges-abolition-1.2033456

Metlay, D. (1999). Institutional trust and confidence: A journey into a conceptual quagmire. In Cvetkovich C. \&Löfsted, R., Eds., Social Trust and the Management of Risk, (pp.100116). London: Earthscan. 
Midden, C. J. H., \& Huijts, N. M. A. (2009). The role of trust in the affective evaluation of novel risks: The case of CO2 storage. Risk Analysis, 29(5), 743-751. doi:10.1111/j.15396924.2009.01201.x

Myers, D. G. (2004). Theories of emotion. In Psychology (7th Ed.) (p.500). NY: Worth Publishers.

Nabi, R. L. (2003). Exploring the framing effects of emotion: Do discrete emotions differentially influence information accessibility, information seeking, and policy preference? Communication Research, 30(2), 224-247. doi:10.1177/0093650202250881

Nancarrow, B. E., Porter, N. B., \& Leviston, Z. (2010). Predicting community acceptability of alternative urban water supply systems: A decision making model. Urban Water Journal, 7(3), 197-210. doi:10.1080/1573062X.2010.484500

Nauta, M. J., Fischer, A. R. H., van Asselt, E. D., de Jong, A. E., Frewer, L. J., \& de Jong, R. et al. (2008). Food safety in the domestic environment: The effect of consumer risk information on human disease risks. Risk Analysis, 28(1), 179-192. doi:10.1111/j.15396924.2008.01012.x

Perlaviciute, G., \& Steg, L. (2014). Contextual and psychological factors shaping evaluations and acceptability of energy alternatives: integrated review and research agenda. Renewable and Sustainable Energy Reviews, 35, 361-381. doi:10.1016/j.rser.2014.04.003

Perlaviciute, G., Steg, L., Hoekstra, E., \& Vrieling, L. (2017). Perceived risks, emotions, and policy preferences: A longitudinal survey among the local population on gas quakes in the Netherlands. Energy Research \& Social Science, 29, 1-11. doi:10.1016/j.erss.2017.04.012 
Peters, E. M., Burraston, B., \& Mertz, C. K. (2004). An emotion-based model of risk perception and stigma susceptibility: Cognitive appraisals of emotion, affective reactivity, worldviews, and risk perceptions in the generation of technological stigma. Risk Analysis, 24(5), 1349-1367. doi:10.1111/j.0272-4332.2004.00531.x

Petty, R. E., \& Cacioppo, J. T. (1986). The elaboration likelihood model of persuasion. In Communication and Persuasion (pp. 1-24). NY: Springer.

Poortinga, W., \& Pidgeon, N. F. (2003). Exploring the dimensionality of trust in risk regulation. Risk Analysis, 23(5), 961-972. doi: 10.1111/1539-6924.00373

Poortinga, W., \& Pidgeon, N. (2005). Trust in risk regulation: Cause or consequence of the acceptability of GM food? Risk Analysis, 25(1), 199-209. doi:10.1111/j.02724332.2005.00579.x

Poortinga, W., \& Pidgeon, N. (2006). Prior attitudes, salient value similarity, and dimensionality: Toward an integrative model of trust in risk regulation. Journal of Applied Social Psychology, 36(7), 1674-1700. doi:10.1111/j.0021-9029.2006.00076.x

Power, M. J., Haynes, A., \& Devereux, E. (2015). Reasonable people v the sinister fringe: Interrogating the framing of Ireland's water charge protestors through the media politics of dissent. Working paper 2015-01. Department of Sociology, University of Limerick, 2015. $\begin{array}{lll}\text { Retrieved from: } & \text { from }\end{array}$ http://www.ulsites.ul.ie/sociology/sites/default/files//Reasonable\%20People\%20v\%20the \%20Sinister\%20Fringe.pdf

RedC. (2014). General election opinion poll. Dublin: RedC Research \& Marketing, 2014. 
Renshon, J., \& Lerner, J. S. (2012). The role of emotions in foreign policy decision making. Encyclopedia of Peace Psychology, 313-317. Retrieved from: http://projects.iq.harvard.edu/sites/projects.iq.harvard.edu/files/lernerlab/files/renshon_ler $\underline{\text { ner_inpress.pdf }}$

Right2Water (2014). Congratulations on another successful demonstration. Right2Watercampaign developing next steps. Retrieved from: http://www.right2water.ie/blog/congratulations-another-successful-demonstration\%E2\%80\%93-right2water-campaign-developing-next-steps

Ryan, N. (2014). Water charges were scrapped in the mid-'90s, but what exactly happened? Thejournal.ie, 2014 November 9. Retrieved from: http://www.thejournal.ie/water-chargesscrapped-1996-1997-1770613-Nov2014/

Schuitema, G., Steg, L., \& Forward, S. (2010a). Explaining differences in acceptability before and acceptance after the implementation of a congestion charge in Stockholm. Transportation Research Part A: Policy and Practice, 44(2), 99-109. doi:10.1016/j.tra.2009.11.005

Schuitema, G., Steg, L., \& Rothengatter. J. A. (2010b). The acceptability, personal outcome expectations, and expected effects of transport pricing policies. Journal of Environmental Psychology, 30(4), 587-593. doi:10.1016/j.jenvp.2010.05.002

Siegrist, M. (1999). A causal model explaining the perception and acceptance of gene technology. Journal of Applied Social Psychology, 29(10), 2093-2106. doi:10.1111/j.1559-1816.1999.tb02297.x 
Siegrist, M. (2000). The influence of trust and perception of risks and benefits on the acceptance of gene technology. Risk Analysis, 20(2), 195-203. doi: 10.1111/02724332.202020

Siegrist, M., \& Cousin, M. E., \& Kastenholz, H., \& Wiek, A. (2007). Public acceptance of nanotechnology foods and food packaging: The influence of affect and trust. Appetite, 49(2), 459-466. doi:10.1016/j.appet.2007.03.002

Siegrist, M., Cvetkovich, G., \& Roth, C. (2000). Salient value similarity, social trust, and risk/benefit perception. Risk Analysis, 20(3), 353-362. doi:10.1111/0272-4332.203034

Siegrist, M., Earle, T. C., \& Gutscher, H. (2003). Test of a trust and confidence model in the applied context of electromagnetic field (EMF) risks. Risk Analysis, 23(4), 705-716. doi: $10.1111 / 1539-6924.00349$

Sjöberg, L. (2007). Emotions and risk perception. Risk Management, 9(4), 223-237. doi:10.1057/palgrave.rm. 8250038

Slovic, P. (1999). Trust, emotion, sex, politics, and science: Surveying the risk-assessment battlefield. Risk Analysis, 19(4), 689-701. doi:10.1111/j.1539-6924.1999.tb00439.x

Slovic, P., Finucane, M. L., Peters, E., \& MacGregor, D. G. (2004). Risk as analysis and risk as feelings: Some thoughts about affect, reason, risk, and rationality. Risk Analysis, 24(2), 311-322. doi:10.1111/j.0272-4332.2004.00433.x

Slovic, P., Flynn, J., \& Layman, M. (1991). Perceived risk, trust, and the politics of nuclear $\begin{array}{llll}\text { waste. } & \text { Science, } & \text { Retrieved } 1603-1607 . & \text { from }\end{array}$ https://search.proquest.com/docview/213559844?accountid=17192 
Smith, N., \& Leiserowitz, A. (2014). The role of emotion in global warming policy support and opposition. Risk Analysis, 34(5), 937-948. doi:10.1111/risa.12140

Steg, L., Dreijerink, L., \& Abrahamse, W. (2005). Factors influencing the acceptability of energy policies: A test of VBN theory. Journal of Environmental Psychology,25, 415-425. doi:10.1016/j.jenvp.2005.08.003

Steg, L., Dreijerink, L., \& Abrahamse, W. (2006). Why are energy policies acceptable and effective? Environment and Behavior, 38(1), 92-111. doi:10.1177/0013916505278519

Stern, P. C. (2000). New environmental theories: Toward a coherent theory of environmentally significant behavior. Journal of Social Issues, 56(3), 407-424. doi:10.1111/0022-4537.00175

Stoutenborough, J. W., Sturgess, S. G., \& Vedlitz, A. (2013). Knowledge, risk, and policy support: Public perceptions of nuclear power. Energy Policy, 62, 176-184. doi:10.1016/j.enpol.2013.06.098

Tabachnick, B. G., \& Fidell, L. S. (2001). Using Multivariate Statistics (4th ed.). Boston, MA: Allyn and Bacon

Tausch, N., \& Becker, J. C. (2013). Emotional reactions to success and failure of collective action as predictors of future action intentions: A longitudinal investigation in the context of student protests in Germany. British Journal of Social Psychology, 52(3), 525-542. doi:10.1111/j.2044-8309.2012.02109.x

Truelove, H. B. (2012). Energy source perceptions and policy support: Image associations, emotional evaluations, and cognitive beliefs. Energy Policy, 45, 478-489. doi:10.1016/j.enpol.2012.02.059 
van Zomeren, M., Spears, R., Fischer, A. H., \& Leach, C. W. (2004). Put your money where your mouth is!: Explaining collective action tendencies through group-based anger and group efficacy. Journal of Personality and Social Psychology, 87(5), 649-664. doi: $10.1037 / 0022-3514.87 .5 .649$

Visschers, V. H. M., \& Siegrist, M. (2008). Exploring the triangular relationship between trust, affect, and risk perception: A review of the literature. Risk Management,10, 156167. doi:10.1057/rm.2008.1

Visschers, V. H. M., \& Siegrist, M. (2014). Find the differences and the similarities: Relating perceived benefits, perceived costs and protected values to acceptance of five energy technologies. Journal of Environmental Psychology, 40, 117-130. doi:10.1016/j.jenvp.2014.05.007

Vroom, V. (1964). Work and Motivation. New York: Wiley

Watson, D., Clark, L. A., \& Tellegen, A. (1988). Development and validation of brief measures of positive and negative affect: the PANAS scales. Journal of Personality and Social Psychology, 54(6), 1063. doi:10.1037/0022-3514.54.6.1063

Zajonc, R. B., (1980). Feeling and thinking: preferences need no inferences. American Psychologist, 35, 151-175. doi:10.1037/0003-066X.35.2.151 
Table 1. Mean, standard deviation, Pearson's correlation and Cronbach $\alpha$ of the variables used in the study

\begin{tabular}{|c|c|c|c|c|c|c|}
\hline & $\begin{array}{l}\text { Acceptance } \\
\text { (AC) }\end{array}$ & $\begin{array}{c}\text { Expected Costs } \\
\text { (EC) }\end{array}$ & $\begin{array}{c}\text { Expected } \\
\text { Benefits (EB) }\end{array}$ & $\begin{array}{c}\text { Negative } \\
\text { Emotions (NE) }\end{array}$ & $\begin{array}{c}\text { Positive Emotions } \\
\text { (PE) }\end{array}$ & $\begin{array}{c}\text { Trust Government } \\
\text { (TG) }\end{array}$ \\
\hline $\mathbf{A C}$ & - & $-0.47 * * *$ & $0.65 * * *$ & $-0.72 * * *$ & $0.61 * * *$ & $0.54 * * *$ \\
\hline EC & & - & $-0.26 * * *$ & $0.50 * * *$ & $-0.36 * * *$ & $-0.33 * * *$ \\
\hline EB & & & - & $-0.52 * * *$ & $0.49 * * *$ & $0.46 * * *$ \\
\hline NE- & & & & & $-0.45 * * *$ & $-0.52 * * *$ \\
\hline PE- & & & & & - & $0.40 * * *$ \\
\hline TG- & & & & & & - \\
\hline Cronbach $\alpha$ & 0.87 & 0.81 & 0.87 & 0.91 & 0.81 & 0.92 \\
\hline Range & $1-5$ & $1-25$ & $1-25$ & $1-5$ & $1-5$ & $1-5$ \\
\hline Mean & 3.34 & 16.39 & 14.55 & 2.41 & 1.91 & 2.79 \\
\hline SD & 1.13 & 5.97 & 5.69 & 1.24 & 0.97 & 0.91 \\
\hline
\end{tabular}

$* \mathrm{p}<0.10, * * \mathrm{p}<0.05, * * * \mathrm{p}<0.01, \mathrm{n}=505$ individuals 
Table 2. Reliability and convergent validity

\begin{tabular}{|c|c|c|c|c|c|}
\hline $\begin{array}{c}\text { Construct } \\
\text { \& Items }\end{array}$ & $\begin{array}{c}\text { Factor } \\
\text { loadings }\end{array}$ & $\begin{array}{c}\text { Robust } \\
(t \text {-value })\end{array}$ & $\mathbf{C A}$ & $\mathbf{C R}$ & AVE \\
\hline \multicolumn{6}{|c|}{ Acceptance (AC) } \\
\hline$\overline{A C \_2}$ & 0.84 & 25.90 & \multirow{3}{*}{0.88} & \multirow{3}{*}{0.88} & \multirow{3}{*}{0.70} \\
\hline $\mathrm{AC}_{-}^{-} 4$ & 0.78 & 20.38 & & & \\
\hline $\mathrm{AC}_{-}^{-} 5$ & 0.89 & 29.91 & & & \\
\hline \multicolumn{6}{|c|}{ Expected Costs (EC) } \\
\hline EC_1 & 0.72 & 18.90 & \multirow{4}{*}{0.81} & \multirow{4}{*}{0.82} & \multirow{4}{*}{0.53} \\
\hline $\mathrm{EC}_{-}^{-2}$ & 0.79 & 24.45 & & & \\
\hline $\mathrm{EC}_{-}^{-3}$ & 0.74 & 21.93 & & & \\
\hline EC_4 & 0.66 & 16.88 & & & \\
\hline \multicolumn{6}{|c|}{ Expected Benefits (EB) } \\
\hline EB_1 & 0.78 & 23.58 & \multirow{4}{*}{0.87} & \multirow{4}{*}{0.88} & \multirow{4}{*}{0.65} \\
\hline EB_2 & 0.89 & 28.01 & & & \\
\hline EB_3 & 0.88 & 29.19 & & & \\
\hline EB_4 & 0.65 & 17.83 & & & \\
\hline \multicolumn{6}{|c|}{ Negative Emotions (NE) } \\
\hline NE_1 & 0.86 & 28.76 & \multirow{5}{*}{0.91} & & \multirow{5}{*}{0.66} \\
\hline NE_3 & 0.80 & 25.31 & & & \\
\hline NE_4 & 0.79 & 28.54 & & 0.91 & \\
\hline NE_5 & 0.82 & 32.61 & & & \\
\hline NE_6 & 0.79 & 18.70 & & & \\
\hline \multicolumn{6}{|c|}{ Positive Emotions (PE) } \\
\hline PE_1 & 0.77 & 18.59 & \multirow{4}{*}{0.84} & \multirow{4}{*}{0.84} & \multirow{4}{*}{0.58} \\
\hline PE_2 & 0.72 & 15.82 & & & \\
\hline PE_4 & 0.82 & 21.51 & & & \\
\hline PE_5 & 0.79 & 20.98 & & & \\
\hline \multicolumn{6}{|c|}{ Trust Government (TG) } \\
\hline TG_1 & 0.86 & 29.74 & & & \\
\hline TG_2 & 0.83 & 28.51 & & & \\
\hline TG_3 & 0.85 & 29.49 & 0.92 & 0.92 & 0.70 \\
\hline TG_4 & 0.76 & 22.78 & & & \\
\hline TG_5 & 0.89 & 30.53 & & & \\
\hline
\end{tabular}

Note.AC_No.; EC_No.; EB_No.; NE_No;PE_No.; TG_No. are the items for each factor. $A C_{-} 1, A_{-} \_3, N E \_2$; PE_3 items were eliminated during the confirmatory factor analysis (CFA). 
Table 3. Discriminant validity

\begin{tabular}{lcccccc}
\hline & $\mathbf{A C}$ & $\mathbf{E C}$ & $\mathbf{E B}$ & $\mathbf{N E}$ & $\mathbf{P E}$ & TG \\
\hline AC & 0.70 & 0.31 & 0.47 & 0.65 & 0.50 & 0.36 \\
EC & {$[-0.65 ;-0.47]$} & 0.53 & 0.08 & 0.34 & 0.18 & 0.14 \\
EB & {$[0.63 ; 0.77]$} & {$[-0.39 ;-0.17]$} & 0.65 & 0.29 & 0.28 & 0.24 \\
NE & {$[-0.86 ;-0.77]$} & {$[0.50 ; 0.67]$} & {$[-0.61 ;-0.47]$} & 0.66 & 0.27 & 0.32 \\
PE & {$[0.65 ; 0.76]$} & {$[-0.53 ;-0.33]$} & {$[0.45 ; 0.60]$} & {$[-0.58 ;-0.45]$} & 0.58 & 0.20 \\
TG & {$[0.52 ; 0.67]$} & {$[-0.48 ;-0.26]$} & {$[0.41 ;-0.57]$} & {$[-0.64 ;-0.49]$} & {$[0.36 ; 0.54]$} & 0.70 \\
\hline
\end{tabular}

Note. AC: Acceptance; EC: Expected Costs; EB: Expected Benefits; NE: Negative Emotions; PE: Positive Emotions; TG: Trust Government. The diagonal represents the average variance extracted; while above the diagonal the shared variances (squared correlations) are represented. Below the diagonal the $95 \%$ confidence interval for the estimated factors correlations is provided 
Table 4. Analysis of Indirect and Total Effects

\begin{tabular}{lccccc}
\hline & AC & EC & EB & NE & PE \\
\hline \multicolumn{1}{l}{ A. Standardised Total effects } & & & \\
\hline EC & $-0.08^{* *}$ & NA & NA & NA & NA \\
EB & $0.24^{* * *}$ & NA & NA & NA & NA \\
NE & $-0.56^{* * *}$ & $0.49^{* * *}$ & $-0.27 * *$ & NA & NA \\
PE & $0.37^{* * *}$ & $-0.17^{* *}$ & $0.30^{* * *}$ & NA & NA \\
TG & $0.59^{* * *}$ & $-0.37^{* *}$ & $0.49^{* * *}$ & $-0.57^{* * *}$ & $0.45^{* * *}$ \\
\hline B. Standardised Indirect effects & & & \\
\hline EC & NA & NA & NA & NA & NA \\
EB & NA & NA & NA & NA & NA \\
NE & $-0.11^{* * *}$ & NA & NA & NA & NA \\
PE & $0.09^{* * *}$ & NA & NA & NA & NA \\
TG & $0.53^{* * *}$ & $-0.35^{* * *}$ & $0.29^{* * *}$ & NA & NA \\
\hline
\end{tabular}

$* \mathrm{p}<0.10, * * \mathrm{p}<0.05, * * * \mathrm{p}<0.01, \mathrm{NA}=$ non-applicable
Note. AC: Acceptance; EC: Expected Costs; EB: Expected Benefits; NE: Negative Emotions; PE: Positive Emotions; TG: Trust Government. 
Table 5. Regression analysis of 'acceptance of the policy'as a function of emotions-items

\begin{tabular}{lcccc}
\hline \multicolumn{1}{c}{ Indep. variables } & $\beta$ & $\mathrm{t}(\mathrm{p})$ & $95 \%$ CI & $\mathrm{VIF}$ \\
\hline Angry & -0.364 & $-8.244(0.00)$ & {$[-0.42,-0.30]$} & 2.921 \\
\hline Deceived & -0.117 & $-2.988(0.00)$ & {$[-0.17,-0.07]$} & 2.313 \\
\hline Frustrated & -0.098 & $-2.167(0.03)$ & {$[-0.16,-0.04]$} & 3.057 \\
\hline Irritated & -0.087 & $-1.838(0.07)$ & {$[-0.15,-0.03]$} & 3.364 \\
\hline Hostile & -0.197 & $-4.986(0.00)$ & {$[-0.26,-0.14]$} & 2.355 \\
\hline Optimistic & 0.084 & $2.260(0.02)$ & {$[0.02,0.15]$} & 2.065 \\
\hline Enthusiastic & & & & \\
\hline Satisfied & 0.119 & $3.333(0.00)$ & {$[0.06,0.18]$} & 1.926 \\
\hline Relaxed & 0.097 & $2.510(0.01)$ & {$[0.03,0.16]$} & 2.256 \\
\hline Note: $\beta=$ Standardized Regression Coefficient; CI= Confidence Interval; VIF = Variance Inflation & & & \\
\hline
\end{tabular}




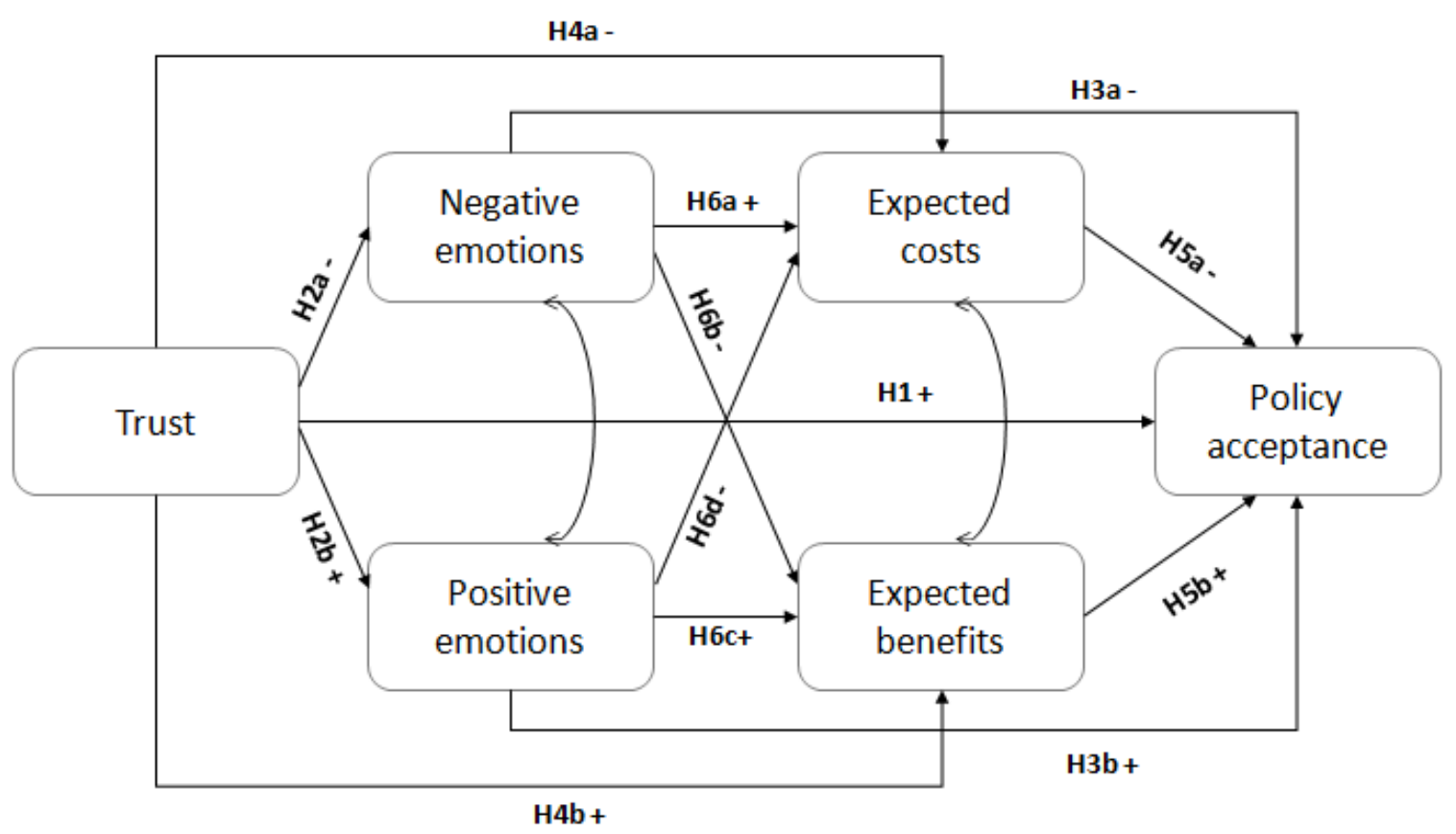

Figure 1: Summary of main hypotheses. 


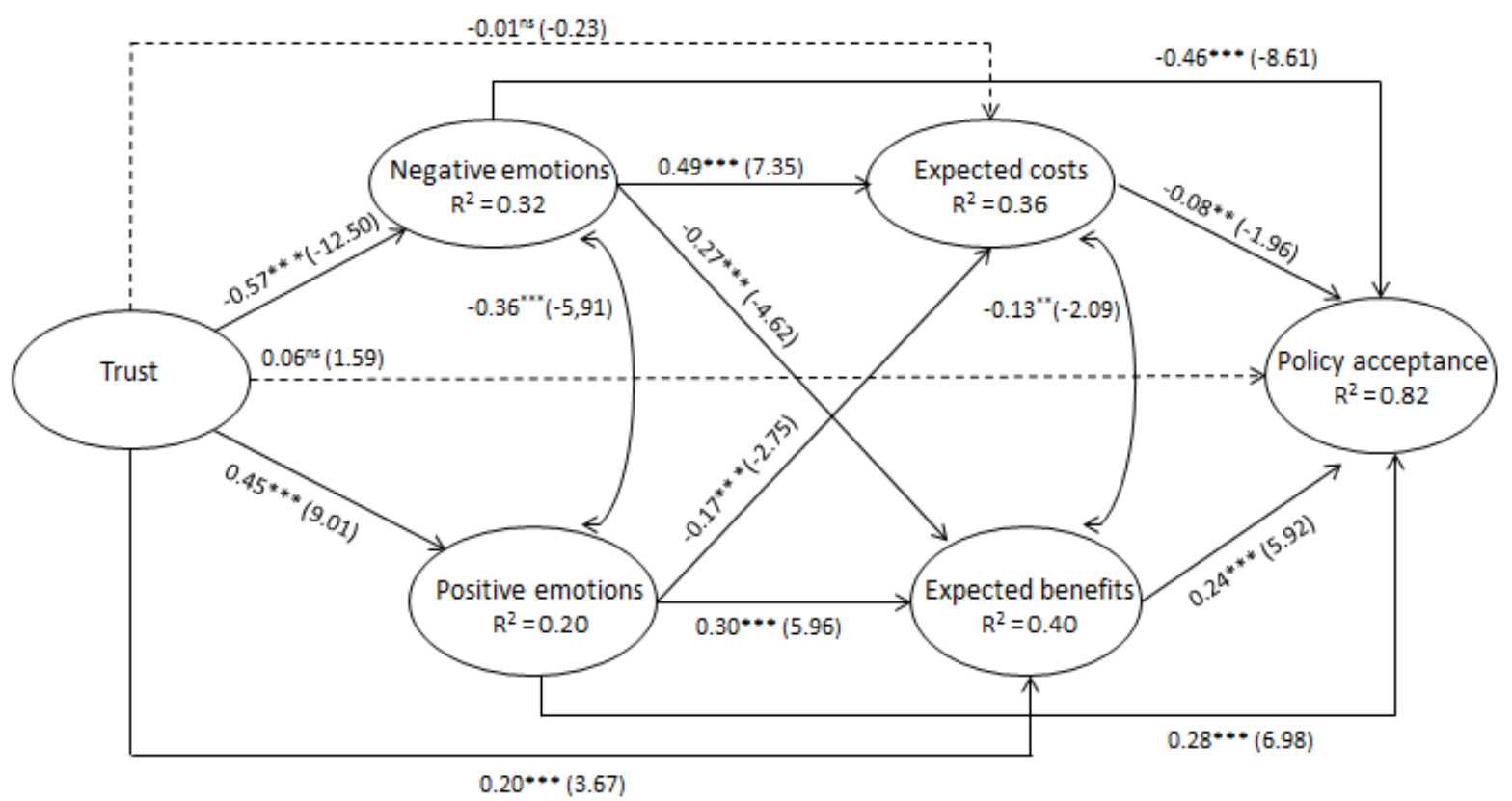

Figure 2. The influence of trust, emotions and expected costs and benefits on policy acceptance. The dashed arrows are non-significant paths in the model. Regression coefficients are the standardized estimates. $\mathrm{R}^{2}$ denotes the amount of variance explained. Significance of coefficients is indicated, $* \mathrm{p}<.10, * * \mathrm{p}<.05 * * * \mathrm{p}<.01$ 